\title{
Study and Enlightenment of the In-Situ Urbanization of Rural Areas in China in the Background of New Pattern Urbanization-Taking Zhanqi Village, Pi County for Instance
}

\author{
Shiqin Guo, Jie Zou \\ School of Economics and Management, Southwest Jiaotong University, Chengdu, China \\ Email: shiqinguo88@126.com, zoujie765@outlook.com \\ Received 7 August 2015; accepted 12 September 2015; published 15 September 2015 \\ Copyright (C) 2015 by authors and Scientific Research Publishing Inc. \\ This work is licensed under the Creative Commons Attribution International License (CC BY). \\ http://creativecommons.org/licenses/by/4.0/

(c) (i) Open Access

\begin{abstract}
The in-situ urbanization of rural areas is a kind of model promoting urbanization appeared in the special national condition of China. It is an inevitable choice for promoting development of small towns. The development pattern of in-situ urbanization is different from the traditional one. The change of county economy and industrial structure and the transform of production mode and lifestyle both reflect these differences. Based on such recognition, combining the background of current new pattern urbanization and the stage background of the New Rural Construction, this article takes Zhanqi Village, Pi County, Chengdu City-one model village of overall urban and rural development and new rural construction-for instance, and analyzes the prerequisite which is necessary for promoting in-situ urbanization of countryside, so that we can get revelation and reflection from this article.
\end{abstract}

\section{Keywords}

In-Situ Urbanization, New Countryside, Property Rights System Reform, Industry Intensive Development, New Pattern Community

\section{Introduction}

After the reform and opening up, the process of urbanization in China has been advancing rapidly and conti-

How to cite this paper: Guo, S.Q. and Zou, J. (2015) Study and Enlightenment of the In-Situ Urbanization of Rural Areas in China in the Background of New Pattern Urbanization-Taking Zhanqi Village, Pi County for Instance. Open Journal of Social Sciences, 3, 137-144. http://dx.doi.org/10.4236/jss.2015.39019 
nuously, the social structure has changed a lot; the rate of urbanization has been improved from $17.92 \%$ in 1978 to $53.73 \%$ in 2013, improved 1.02 percentage point each year. According to the "National Standard of The People's Republic of China: Term Standard of City Planning”, the so-called urbanization refers to the historical process that the producing and living mode of human is being transformed from countryside to city. Its concrete manifestation was the process that the rural population transformed into the urban population and city got development and perfection constantly. Telling from the scientific connotation, it refers to a multiple, wide, and longitudinal integrated process that the rural population transfers to city and town and lives in there; the lifestyle and value change to urban pattern; the occupation range transforms from the primary industry to secondary and tertiary industry. In-situ rural urbanization is not like the traditional urbanization; it is a special concept raised from China's national conditions under the urban-rural dual structures. It is not only reflected in that people's production and live areas are changed from countryside to city and town, but also prominently in the social industrial structure change in the county district, and the production mode, life style and conception change from countryside to city and town. Such as achievement of industrial upgrading and intensive development, the rural surplus labor and farming population transfered in-situ to secondary and tertiary industries, and the way of life in rural areas changed from traditional distributed small family courtyards to convenient new communities in the county district.

Since 1950s, most villages in China have gone through the transformation of natural village to administrative village. At the same time, under the intervention of state power, rural economy began carrying out the collective ownership form, collective economic organization such as mutual-aid team, cooperative and people's commune appeared one by one. In a whole, through innovation and strategic adjustment, the rural economy and society of China have achieved stage development since the end of 1970s. However, with the speeding pace of the urbanization process in China and the development of industrialization, rural development is facing problems such as decline of agricultural capacity, serious erosion of cultivated land resources and the destroyed ecological environment. In recent years, after the vigorous New Rural Construction and all-sided rural property right system reform, rural development in China has made remarkable progress. But Three Rural Issues have not still gotten basic settlement. There is still a huge gap between the urban and rural area. This fact requires New Rural Construction to get new transformation and upgrade on the basis of stage progress. Therefore, in the background that the new pattern urbanization demands coordinated development of the large, middle and small scale cities and towns, and the urbanization quality improves comprehensively, China needs to combine the new rural construction to promote the in-situ urbanization of rural areas actively, under guidance of the thinking of high efficient and intensive, scientific and sustainable development, and urban and rural integration. So people can enjoy the modern and civilized achievement of urban and rural construction.

\section{Literature Review}

Concerning the in-situ urbanization issue, most internal scholars study it from the point of view of urbanization. For example, Ye, K.-L. (1986) thought that China's urbanization should be based mainly on small towns, developing small towns in-situ relying on township enterprises, and finally achieving urbanization of rural areas, through complying the "mediator" that the rural surplus labor transfer, industrial structure adjustment and agricultural modernization [1]. Chen, M.-Q. (2004) though that urbanization of the rural areas was an indispensible approach in the process of China's urbanization [2]. Zhu, H.-G. (2005) thought that rural urbanization was a concept raised under the particular national condition "partition of urban and rural," a transition to the final purpose that realization of urbanization [3]. Wang, J.-G. (2005) thought that rural urbanization was a necessary process in the advancement of urbanization, which contained three successive and impassable steps that rural urbanization, town urbanization, and city modernization [4]. Analysis of Pan, H.-Sh. (2010) concluded that the in-situ urbanization was an essential choice to promote the new pattern urbanization, the city resources should radiated to the surrounding towns and villages, famers' in-situ pioneering should be encouraged, in order to increase income, change the production manner, and live a city life [5]. Zhong, Sh.-Ch. (2013) also thought that China's urbanization must insist on two-steps manner that transition from the in-situ rural urbanization to urbanization; rural in-situ urbanization was the primary stage of urbanization, the large-scale migration type of urbanization was the advanced stage of urbanization in China [6]. There are some scholars studied the in-situ urbanization from the angle of small town development, for example, Wang, Zh.-Y. (2000) demonstrated the importance of small town development from the aspects of improving farmer's income, promoting industry develop- 
ment, realizing agriculture modernization, and etc.; he thought that small town was an important carrier to realize the agriculture modernization, rural industrialization and rural urbanization, was the big strategy to promote rural development [7]. Lei, J. (2004) [8] analyzed the small town and urbanization of rural areas in Xinjiang district. Cui, Sh.-P. and Zhao, Q.-Y. (2013) analyzed the urbanization practice in southern Jiangsu; they thought the development of small town should keep in time with the new village construction, taking actions that suit local circumstances and choosing development policy scientifically to build livable and industry suitable small town. They also thought urbanization in county district could make numerous rural residents change to city residents in-situ or nearby, achieve "leave the land without leaving the rural". Therefore, the urbanization in county district is called in-situ urbanization [9].

The above studies provided certain development thinking and reference for promoting rural urbanization in China, but most of the scholars discussed the issue of rural urbanization from the angles of promoting process and small town development, less studies researched the issue from the point of view of in-situ urbanization. The target of urbanization is realizing relative centralization of population, economy and society, and transforming of social and economic structure. The advancement of in-situ rural urbanization is not only beneficial to reduce the cost of labor transfer, improve the benefit of the social and economic development, and promote the development of small towns; but also beneficial to promote the new rural construction and rural economic development and upgrade, then realize the transformation of economic and social structure overall. Therefore, this article has important realistic meaning to study the problems of rural urbanization in our country from the perspective of advancing in-situ urbanization.

\section{Case Brief}

The Zhanqi village in Pi County is located on the border of Pengzhou, Dujiangyan, and Pi County. The village has an area of 2.06 square kilometers, cultivated land area of $2163 \mathrm{mu}, 530$ peasant households, and 1715 registered agricultural population in 2012. Since 2006, under Chengdu city's demand of “three centralization” of balancing urban and rural development, Zhanqi village began its land concentration and transference, which is nearly completed at present. In April 2009, Zhanqi completed its “new community” construction, and guided residents to centralized living. There are 12 production and process enterprises; the economy is mainly based on agriculture products processing, organic vegetables, ecological leisure and tourism agriculture. In 2012, the total assets of village collective economic was more than 20 million Yuan, the disposable income was nearly 4 million Yuan. In 2007, the village farmer's net income per capita is less than 6000 Yuan, but rose to 12,320 Yuan/ person/year, the average annual growth was 1563 Yuan.

Zhanqi of Pi County is a common village in the western plain of Sichuan province. Since 2007 when Chengdu city was approved as "pilot zone of overall rural and urban development," its development speed ranks first in the whole country, Zhanqi village is a typical representative springing up in this overall rural and urban development. Since 2006, Zhanqi started to turn towards the market, and implement integrated management and circulation of land, created a new type of agricultural industrialization management system of the "village collective-enterprise-cooperatives”, and realized interactive development of the primary, secondary and tertiary industry. They built new community and guided farmers to concentrate in it, implemented democratization and modernization management of village and community affairs. In recent years, Zhanqi took adjust measures to local conditions to explore the characteristic development pattern, realized great-leap-forward development, became "demonstration village" of overall rural and urban development of Chengdu city and "star village" of the public eye. Through field investigation, the author found that, as a typical example of China's urban and rural development as a whole, Zhanqi village's development model has beyond common sense of the category of rural development, it is more consistent with the actual requirements of the in-situ rural urbanization in China. Therefore, this article has important significance to take Zhanqi village as a typical representative example for studying the problem of in-situ rural urbanization in China.

\section{Essential Elements of In-Situ Rural Urbanization and the Practice of Zhanqi Village}

\subsection{People Oriented, Scientifically Planed "Garden Town"}

Scientific planning is the beginning of good development. No matter the new pattern urbanization or the new 
countryside construction, the people oriented core idea should keep the same. In the village management structure, although the grass-roots leadership is the leader of rural community management and collective economy development, grass-roots leadership with pioneering spirit, strong cohesion and rallying point will be better able to lead the masses to rich path; the peasants is the real main body of rural economy. In order to realize the in-situ urbanization in rural areas and construction of new countryside, we must always adhere to the core conception of people-oriented and the farmer main body status, and scientifically plan combining with the local actual conditions and characteristic.

After the reform and opening up, with the rise and rapid development of township enterprises, Zhanqi village also successively set up brick factory, roe factory and other township enterprises, established certain basis for further development. In 2007, during the situation of China's new countryside construction, Zhanqi began integrate the village resources with nearby resources, set the target of building "world garden city", insist on the combining of ecological development and modern civilization, and plan its development path scientifically. First, fully respect the principal position of farmers, make confirmation of land rights and land improvement, implement land centralization and transference, in order to liberate the production force and promote the free flow of production factors. Secondly, establish agricultural cooperative society, construct modern agricultural industrial park, develop scale, industrialization and modernization agriculture, exploit characteristic tourism and leisure agriculture, use the first industry to stimulate the tertiary industry, to form a interactive mechanism of first industry and tertiary industry. Thirdly, actively develop the collective enterprises and township enterprises; attract foreign investment enterprise, to promote the development of agriculture industrialization and the interaction of the primary industry and the secondary industry. Fourthly, based on the requirements of the "three concentration" of Chengdu city, construct Zhanqi's “new community” positively to implement farmers' concentration living; based on countryside, administer Zhanqi community according to urban standard, strengthen the construction of community infrastructure, perfect community farmers’ education, health care, pension, sanitation and other basic public service supply, and build “culture compound” to rich farmers' amateur life, to make the farmers "living in the countryside, enjoy the city service”. The development path planning of Zhanqi village as shown in Figure 1.

\subsection{Breaking the Constraint of Property Right System, Liberating Agriculture Production Force}

With the rapid advancement of urbanization and industrialization, China's agriculture production appears serious

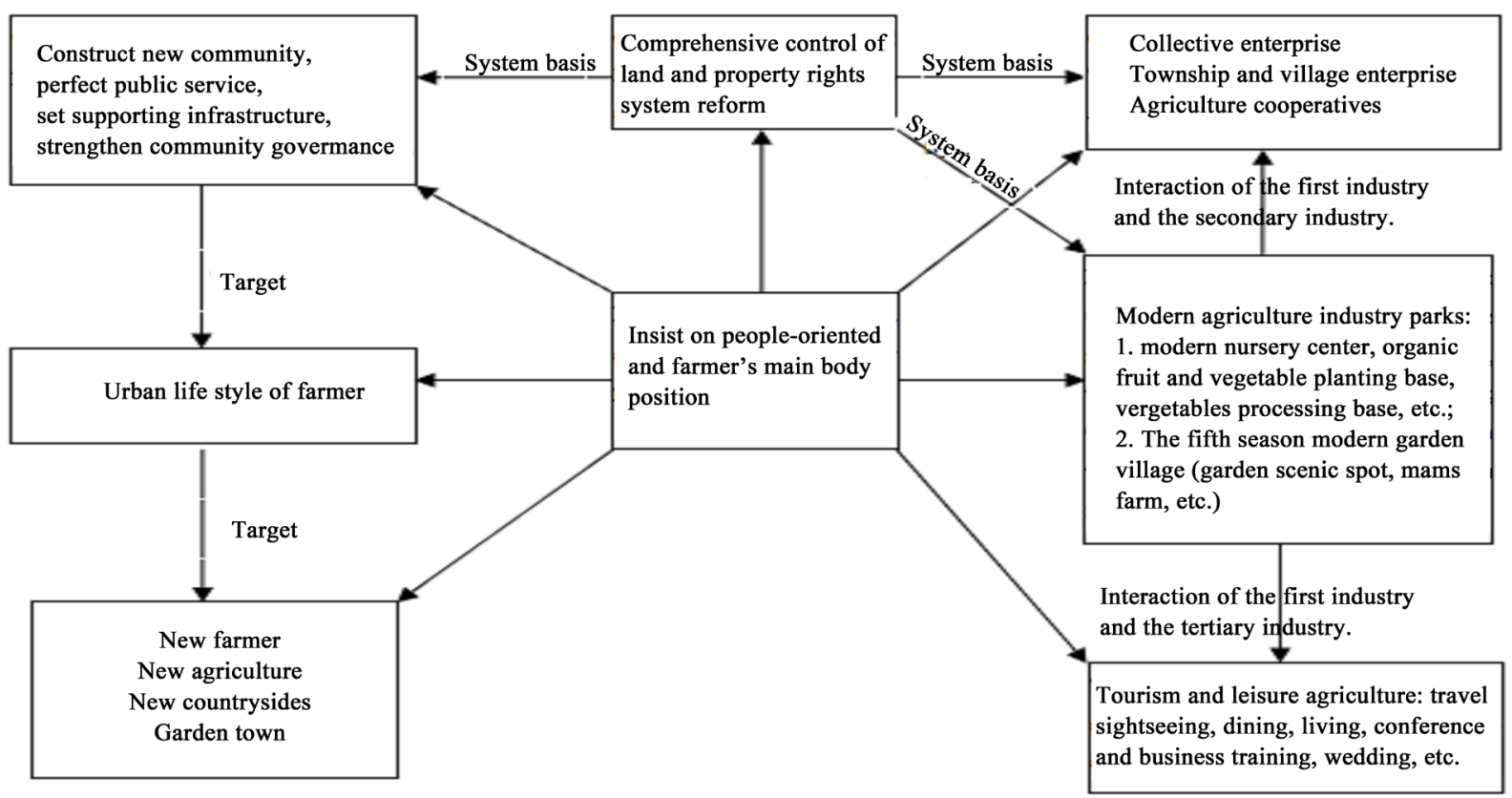

Figure 1. Zhanqi Village’s development path planning. Data source: the author drawing. 
problem. On the one hand, a large number of cultivated lands lose, and the farmland-abandoning phenomenon is serious, losing its economic function. According to data from the Ministry of Land and Resources, in the end of 2008, there is only 1.82574 billion mu of arable area throughout the country, which has been close to the bottom of the 1.8 billion mu red line. On the other hand, the investment level in agriculture production is low, the cultural quality of labor force is on the low side, and the agricultural development funds are seriously short. As a large number of relatively high cultural level of young adults moving to city and town, high quality rural labor force resources is more scarce, the rural economy was forced to rely on secondary labor force. For a long time, under the urban and rural dual system and the twisted price mechanism, the rural capital is transferred from agriculture department to industry department, from countryside to city through financial channel and other hidden ways, the capital flows are seriously tilted to the city. It is estimated that about 600 billion Yuan of capital was taken out from countryside [10]. The agricultural production resources mainly came from farmers' small-scale, short term and decentralized investment; it's difficult to get a long-term development. With the development of the market economy, the traditional family contract responsibility system makes the land owned by the collective; farmers only contract right to use and manage, but have no free disposition right, which lead to low marketization of the most basic production factors such as land, labor and capital. Therefore, in order to promote in-situ urbanization of the rural area and make the rural economy develop sustainably for a long time, we must liberate the productive force largely and reform the property rights, to make reasonable and free flow of all kinds of production elements, and make optimal allocation of resources.

In July 2007, China issued and implemented the new Law on Land Circulation, began the second national land survey and the pilot work of rights confirmation of rural land. The rights confirmation and circulation of rural land are the keys of the rural property right system reform. Land rights confirmation is to determine the ownership of property right of land, making the real rights ownership of the rural contracted land, homestead, collective construction land and other possessions clear, returning rights and endowing ability to farmer and collective economic organization. Under the guidance of national and Chengdu's land policies, Zhanqi village began land rights conformation in 2008, and had fully completed the land comprehensive improvement and rights confirmation in August of 2012. The biggest differences between Zhanqi and other villages of Chengdu during the process of land rights confirmation are adhering to the principle of democracy and voluntary and guiding farmers to land concentration at the same time of land confirmation. In June 2010, Zhanqi had realized land concentration fully and unified management by agricultural cooperatives. Through land concentration and circulation, Zhanqi not only liberated its labor forces, improved land circulating efficiency, and optimized resources allocation, but also established a solid basis for the construction of modern agricultural industry park, complementation of agricultural industrialization and scale management.

\subsection{Developing Characteristic Industry, Promoting the Intensive Development of Industry and Interactive Upgrade}

The household contract responsibility system reform broke the constraint of rural people's communes under the highly centralized planned economic system; the rural economy began walking to market. Under the push of market economy, the peasant household of decentralized management is in a weak market position due to lack of bargaining ability. Therefore, some towns began to break tradition and walked into a cooperative road, and set up the agricultural cooperatives, share cooperatives, and other forms of collective cooperation organization one after another, which have improved the degree of organization and marketization of the rural economy. As members of the village collective economic organizations, farmers' wealthier is closely related to the development level of collective economy. The Huaxi, Nanjie, Liuzhuang, Daqiuzhuang and other typical collective economy developed villages appeared after the reform and opening up proved that: rich collective makes rich villagers; poor collective makes poor villagers. Zhanqi attached importance to the development of collective economy at an early time, began from the "Learning from Dazhai in Agriculture" in 1970s; to the establishment of brick factory, roe factory and other collective enterprises after the reform and opening up; and to the development of industrial agriculture and collective enterprise in the situation of balancing urban and rural development, and implementation of the economic development model of “interaction of village, enterprise and farmer”. Through this series of development measures, Zhanqi's village collective economy increased sustainably in recent years. The collective assets were up to 18 million Yuan in 2010 and 23 million Yuan in 2012. The village’s collective disposable income has a rapid growth, from about 800 thousand Yuan in 2010 to 3.82 million Yuan in 
2012. Its collective economy developed stably.

Through energy release from the system innovation in the early years of the reform and opening up, the growth of China's agricultural performance began to slow after the mid-1980s. With the speeding up of urbanization and the rapid growth of population scale, the contradiction between people and land became increasingly sharp; the scattered farmland operation mode has seriously restricted the marketization development and intensive growth of China's agriculture. The theory of Economies of scale says that when production technology function $\mathrm{F}(\mathrm{X})$ meets the condition that if all the $\mathrm{T}>1, \mathrm{~F}(\mathrm{TX})>\mathrm{TF}(\mathrm{X})$ and the factor of Economies of scale $\mathrm{a}=$ $\mathrm{F}(\mathrm{TX}) / \mathrm{TF}(\mathrm{X})>1$, the function is a increasing function of returns to scale. When all the production factors $\mathrm{X}$ increase by a same proportion while the production capacity rising, the production output will get a greater proportion of increase. However, agriculture does not have obvious scale economic benefit like industries; scale economy in the sense of economics is not completely suitable for agricultural production. Many empirical studies (Feder et al., 1992; Olinto, 1995; Burgess, 1997) agree that relationship between the farm scale and the agricultural productivity is a constant [11]. Therefore, breaking through the restraint of the high proportion of people to land, and carrying out appropriate scale operation of farmland and industrial development of agriculture is an effective approach to solve the problem that the rural economic benefit is low, and necessary economic premise to realize intensive development of rural economy and promote in-situ urbanization. In the aspect of industry development, Zhanqi village took a development path of comprehensive interaction of the first, secondary, and tertiary industry, through developing modern agricultural industry and characteristic sightseeing agriculture. At first, promoting agriculture industrialization, achieving interaction of the first and secondary industry. Since 2006, through property right reform and land concentration, Zhanqi guided farmers to land scale operation and centralized circulation. They established agricultural cooperatives, constructed modern agricultural industry park, and spread them to the nearby villages and towns, promoting cross-village scale operation. The industry park adopted regional distribution, divided into planting area and vegetable early-processing zone, which included modern nursery center, controlled atmosphere storages, organic vegetable bas, etc.; through attracting business transactions and foreign investments, Zhanqi introduced large planting household, Chengdu Rongzhen Mushrooms, and other high-end agricultural enterprises. They develop the industrial park by company + farmer pattern, advance integrated management of agricultural products production, processing, sell and circulation, realize the cohesion of the first industry and secondary industry, and promote the scientific, marketization, standardization and industrialization development of the industry park. Secondly, exploiting special tourism agriculture, to realizing interaction of the first industry and tertiary industry. In order to establish its own brand and highlight local characteristics, Zhanqi further rely on its local advantages, develop characteristic agriculture tourism through resource integration. Since 2010, Zhanqi began the project construction of the "fifth season Zhanqi's modern rural village of Chengdu", to develop creative agriculture sightseeing park; and rely on high-tech and high value-added industry to develop agricultural tourism base, gathering specialization, industrialization and sightseeing, leisure and amusement in the integral whole. There are high-tech agricultural sightseeing garden, flower field area, mom farm, and other bases built in the industry park, and forming a complete set to build tourism, catering, accommodation, conference, training, leisure, entertainment and other service bases. It takes agriculture as foothold, makes benign interaction and coordinated development of the first and tertiary industry. Through extending the industry chain and the interaction and upgrading of the three industries, Zhanqi's collective economic income increased steadily. The farmers took their rights of land-contracted management evaluated and became shareholders of the agricultural cooperatives, changing their working modes, widening their employment ways, effectively promoting the agricultural labor force transfer in-situ, and realizing the diversification of income: guaranteed rent of land circulation $+50 \%$ dividend payment of share holding + working income and other operation income. In 2012, the net income per capita of Zhanqi's farmer was 12,320 Yuan, increased by 1.27 times than in 2006, the average annual increased income was 1150 Yuan. In addition, the development of Zhanqi village has a strong radiation to Hengshan, Huohua, Jinxing, Xibei and other villages, driving the peripheral villages and towns to realize clustered industrial development, and settling a solid economic basis for realization of in-situ urbanization.

\subsection{Building New Urban Communities, Improving Public Service and Social Management}

An important exemplification of urbanization is the change of people's production mode and lifestyle, but not only shifting the living and working place from countryside to city. On the one hand, through industry upgrading 
and clustered development, the liberated rural labor forces in Zhanqi came into and work in the township and village enterprises, realizing the in-situ transfer of the agricultural labor forces. On the other hand, under the guidance of the "three centralization" thinking of the coordination of rural and urban development of Chengdu city, Zhanqi began to construct the "new community" on democracy and voluntary basis in August 2007, introduced market main body in the community infrastructure, public service and social management; the supply was classified, the service and management were improved constantly. Zhanqi equipped the community with water supply, sewage treatment and other public facilities; constructed convenient service station, health clinics, preschool education, labor and social security workstation, culture yard, etc.; improved facilities construction and management of police security to promote public infrastructure construction; Strengthened the community management, perfected the management system; strengthened comprehensive control of the village road, environmental health, the botanical garden green space, fire and other public facilities to improve the villagers' living environment for living a convenient city life, making the villagers "live in the countryside, enjoy the city life".

\section{The Important Practical Significance of Promoting In-Situ Rural Urbanization}

For over 30 years of reform and opening up, China have got remarkable achievements on the development of urbanization, but also brought a series of negative outputs at the same time. For example, the land urbanization speed is faster than population urbanization, urban scale expanded blindly; the urbanization and half urbanization problems of rural migrant workers are outstanding; influx of large foreign population led to increasing and expanding of environmental pollution, traffic jams and other city diseases; the development of big, middle, and small cities and towns are not harmonious, the rural economy declines, a large number of young adults transfer to city, the "hollow village" is universal existence; the urbanization away from home leads to serious social problems like left-behind children, rural ageing, "migrant" Spring Festival transport, etc. Therefore, under the guidance of national policies that balancing urban and rural development and promoting urban-rural integration, based on the new urbanization and new rural construction, promoting in-situ rural urbanization has very important practical significance to solve a series of social problems:

Firstly, promoting the in-situ urbanization can develop rural economy. With the rapid development of urban economy after the reform and opening up, not only the senior talents from countryside stay in the city, many young adults in rural areas also transfer to cities, leading to rural labor shortage, vitality loss, imbalance in the structure of rural social and economic dislocation. Therefore, making full use of rural advantages and resources, developing the rural economy with adjust measures to local conditions, attracting and guiding the rural talent and surplus labor to start an undertaking home or work on-site, and pushing in-situ urbanization can enhance the vitality of the rural economy, and promote the rural economic recovery and revitalization.

Secondly, the in-situ urbanization is an effective approach to optimize the Chinese urban system, and promote sustainable development of the urbanization. In urban system in our country, the development of small towns is relative lagged, the basic infrastructure, and public service of which is relatively weak. Promoting development of small town, in-situ urbanization and in-situ transfer of labor force is beneficial not only to promote the system coordination of large, middle and small cities; but also to reduce the social migration cost by realizing "leave the land but not the hometown"; to solve the problem of left-behind children and left-behind old people and other social problems, and slow down the population expansion pressure and problems in large and medium-sized cities at the same time; finally improve the sustainability of the urbanization development.

Thirdly, the in-situ urbanization is an essential choice to realize integration of urban and rural areas. Urban and rural integration is an important development target in China at present. Through development of township and rural enterprises and entity economy, intensive development and industry upgrading, it can sharply increase the economic power, provide economic security for strengthening the villages and towns construction and management, and improving the level of infrastructure and public services; accordingly, improving rural residents' working and living environment, and realizing the urban and rural integration and coordinated development.

\section{Conclusion}

Researching China's rural economic development model after the reform and opening up, we can see that as the market mechanism penetrates deeply into each social domain, a group of "star villages" and advanced villages in economy development spring up. Most of them conform to the premise of market economy, make institutional innovation based on the existing land ownership, implement land scale management and professional manage- 
ment, develop industrial economy, and finally find out their own development path. The development model practice of Zhanqi Village's characteristic small garden town reflects from another side that how to break through the constraints of existing imbalance of population and land scale, to innovate the land management mode and the rural construction structure, in order to realize the scale, industrialization and characteristic development, in the current new pattern urbanization background. In the process of marketization and urbanization, it is hard to avoid the benefit differentiation and resource allocation injustice. Therefore, the villages should make full use of their own conditions, integrate resources, and dig advantages to push on the in-situ urbanization and the revitalization of the rural economy, and form interests union where all participants have a strong sense of community, through restructuring and optimizing industry chain and development of a "sharing" reward system.

\section{References}

[1] Ye, K.-L. (1986) To Discuss the Chinese Urbanization Pattern of Taking Small Town as a Main Body. Management World, 5, 25-37.

[2] Chen, M.-Q. (2004) Analysis on System Obstructions to Small Town Sustainable Development and Countermeasures in China. China Population, Resources and Environment, 14, 58-61.

[3] Zhu, H.-G. (2005) A Brief Narrative Comment on the Study of Rural Urbanization. Journal of Mountain Agriculture and Biology, 24, 448-452.

[4] Wang, J.-G. (2005) On the Urbanization Strategy of China. Journal of SJTU (Philosophy and Social Sciences), 42, 4448.

[5] Pan, H.-S. (2010) The In-Situ Urbanization: A New Road to Urbanization-Investigation and Consideration on Small Town Construction in Zhejiang Province. Chinese Township Enterprises, 11, 46-50.

[6] Zhong, S.-C. (2013) Migration and In-Situ Urbanization: Concurrently Discuss the In-Situ Urbanization of Western China. Economic Research Guide, 185, 165-168.

[7] Wang, Z.-Y. (2000) Developing Small Town Is the Grand Strategy of Driving Rural Economy and Society Development. Issues in Agricultural Economy, 8, 2-6.

[8] Lei, J., Lu, Q., Zhang, J.-D. and Du, H.-R. (2004) Development of Small Town and Rural Urbanization in Xinjiang. China Population, Resources and Environment, 14, 85-90.

[9] Cui, S.-P. and Zhao, Q.-Y. (2013) The Inspiring and Thinking for In-Situ Urbanization of South Jiangsu. Urban Development Studies, 20, 47-51.

[10] Liang, Y. (2006) To Promote Financial Reform and Construct Multi-Level Rural Financial System. Legal and Economic, 119, 60-63.

[11] Tian, C.-H. (2005) Farmland System, Farmland Leasing Market and Farmland Allocation Efficiency. Economic Science Press, Beijing, 264. 